\title{
Outro Mundo, XIII, de Rosa Liksom
}

Pasi Loman ${ }^{1}$

Rosa Liksom (Ylitornio, 01/07/1958) é o nome artístico de Anni Ylävaara, escritora e artista plástica finlandesa. Liksom estudou antropologia e ciências sociais nas universidades de Helsinque, Copenhague e Moscou. Já com o seu primeiro livro, a coleção de contos Yhden yön pysäkki (1985), Liksom ganhou o importante prêmio literário J. H. Erkko. Desde então, ganhou vários outros prêmios literários: em 2011, ganhou o prêmio literário mais importante de seu país, o "Finlandia palkinto", com o romance Hytti nro 6, também finalista do prêmio literário francês "Prix Médicis étranger"; o Prêmio Literário do Conselho Nórdico de melhor livro escandinavo do ano, em 2013; e o prêmio "Strego Europeo" na Itália, em 2014. Em 2016 Liksom recebeu a prestigiosa Ordem das Artes e Letras (Ordre des Arts et des Lettres) na França, uma condecoração concedida pelo Ministério da Cultura que visa reconhecer "as pessoas que se distinguem pela sua criação no domínio artístico ou literário ou pela sua contribuição ao desenvolvimento das artes e das letras na França e no mundo".

Além do sucesso de crítica, Liksom é uma das autoras de maior sucesso comercial da Finlândia. Até agora, por exemplo, o Hytti nro 6 vendeu mais de 100.000 cópias apenas na Finlândia (população de 5 milhões). Traduções de seus livros já foram publicadas em mais de vinte idiomas. Em português, Liksom tem um livro publicado pela editora portuguesa Relógio d'Água, a coleção de contos

1 A tradução foi feita diretamente do original finlandês por Pasi Loman, finlandês radicado no Brasil desde 2006, e revisada por sua esposa Lilia Loman, que possui doutorado em crítica e teoria literária pela University of Nottingham e pós-doutorado pela PUC-SP. Para realizar várias traduções literárias sem fim lucrativo em 2017, incluindo esta, Pasi recebeu bolsas de duas fundações finlandesas: Otavan kirjasäätiö e WSOY:n kirjallisuussäätiö. 
Osparaísos do caminho vaz̧io (1989, tradução de Merja Sinikka Nousia e Marta Duarte Daniel Dias), mas, se não fosse essa coleção de textos nórdicos, permaneceria inédita no Brasil.

Embora Liksom seja mais famosa como escritora, também é mundialmente conhecida como pintora e artista plástica. Porém, apesar de produzir livros e exposições de fotografia, bem como filmes de curta-metragem, Liksom não se considera fotógrafa, mas uma artista que usa a fotografia como uma ferramenta. Em 2016, Rosa Liksom visitou o Brasil como convidada do Festival Internacional de Imagem Valongo (Santos - SP) e da Embaixada da Finlândia. A artista aproveitou a viagem ao Brasil para desenvolver várias outras atividades, que incluíram uma exposição de fotografia na galeria da Pinacoteca Benedito Calixto em Santos - SP, uma oficina sobre técnicas de escrita e sobre como transformar texto em narrativas visuais, e a participação em um evento literário na Livraria Realejo em Santos, onde falou sobre a sua trajetória como escritora e sobre a obra Hytti nro 6.

Até agora Liksom publicou dezessete livros, que incluem coleções de contos, romances, livros infantis e livros de arte. Mesmo tendo feito mais sucesso com o romance Hytti nro 6, Liksom é, de fato, mais conhecida como mestre de contos. Seus contos são frequentemente muito curtos, mini-histórias pequeníssimas, de apenas algumas páginas. Os personagens principais são muitas vezes pessoas que vivem à margem da sociedade e que se encontram em situações absurdas. Liksom usa uma linguagem básica e até crua, adequada para as personagens, mas ao mesmo tempo muito prazerosa de ler. Seus textos mostram um mundo frio, cheio de tragédias e injustiça, mas às vezes terminam com um pouco de esperança em um mundo melhor e na justiça. Apesar de temas pesados, como violência contra mulheres, vício em drogas e racismo, há muito humor nos contos e livros de Liksom. Alguns dos contos são praticamente intraduzíveis, uma vez que se passam na Lapônia e são escritos com o dialeto e o sotaque dessa região, sendo esse aspecto do idioma uma parte fundamental destes textos. Como não existe dialeto da Lapônia em português, ficaria sem graça traduzir esses contos.

A língua finlandesa não faz parte dos idiomas indo-europeus, como faz o português; faz parte da família de línguas urálicas. Consequentemente, o finlandês e o português são dois idiomas bastante diferentes, tanto no vocabulário quanto na gramática. O finlandês, por exemplo, não tem preposições, e em vez disso usa um complexo sistema de declinação que conta com quinze casos. $O$ finlandês também não tem artigos nem gêneros. $O$ finlandês nem tem palavras femininas e masculinas para o pronome em terceira pessoa singular; isso permite que o autor não revele o sexo das personagens se não quiser - Liksom também usa essa ferramenta de vez em quando, embora não no conto aqui traduzido. Devido 
a essas grandes diferenças entre o finlandês e o português, por vezes é bastante difícil manter o estilo do texto original. Em finlandês é possível, por exemplo, ter frases muito compridas e, graças ao sistema de declinações, é fácil acompanhar o pensamento do autor e entender as frases muito longas, que em português ficariam muito confusas. No caso de Rosa Liksom, porém, não encontramos problemas devidos às diferenças dos idiomas; em parte, acreditamos, porque ela prefere frases curtas e sucintas. Para a presente coleção de contos nórdicos, escolhemos um conto típico de Liksom; curto, com situações meio absurdas, violência, mas com uma vingança contra o vilão da história no final. 


\section{Muu mailma, XIII}

Rosa Liksom

Meidän talossa on todella hyvät kerhotilat. Ennen kun talossa asu paljon lapsia ne oli jatkuvassa käytössä. Nyt kun lapsia ei enää ole, me ollaan vuokrattu tilaa ulkopuolisille. Ensin meillä oli vuokralaisena taidekerho Picasso. Se toimi ekan viikon hyvin, mutta sitten kun ne alko maalaamaan, se tärpätin haju nousi tuuletuskanavaa pitkin ylöspäin ja siitä synty soppa. Kolmannessa kerroksessa asunut Manninen valitti, samoin kuudennen kerroksen leski, ja mun piti mennä sanomaan sille kerhon vetäjälle, että ei tästä tule mitään. Pari vuotta ne kerhotilat olivat sitten tyhjillään, mutta kun taloyhtiö tartti tuloja niin Manninen ehdotti, että vuokrataan tilat uudelleen jollekin hajuttomalle kerholle. Mä löysin Metro-lehden halutaan palstalta Vire-kerhon. Sen kerhon takuumiehenä oli SPR, joka lupasi maksaa vuokrat ajallaan. Esitin asian Manniselle ja se innostui. Aluksi siitä porukasta ei ollu mitään harmia. Ne oli sellasta 80 plus -jengiä, jotka pelas bingoa tai jutteli viipalekuvauksista ja homeopatiasta. Mutta kun syksy vaihtui talveksi, alkoivat ikävyydet. Kerran yks kerhon jäsenistä sai kohtauksen ja jouduttiin kutsumaan ambulanssi. Vähän tän tapauksen jälkeen kerhon vapaaehtoisvetäjä kuoli kesken kirjakerhon ja paikalle tilattiin ruumisauto. Manninen sai herneen nenäänsä ja pyysi minua soittamaan SPR:lle, että leikki loppuu tähän. Mä soitin ja taas oli kerhohuoneisto vapaana. Taloon oli kuitenkin tulossa parvekeremontti ja siihen tarvittiin rahaa. Mä löysin Helsingin Sanomista ilmoituksen, jossa Veljespiiri etsi kerhotilaa. Näytin ilmoitusta Manniselle ja Manninen sanoi, että vaikuttaa hyvältä, koska kerhon nimi viittaa kivasti kadotettuun Karjalaan ja siellä asuviin veljeskansoihin. Mä soitin ja sovin tapaamisen kerhon pääsihteerin kanssa. Se oli isänmaallinen nuori mies, oikein oli Suomen lipunkin ommellut takkiinsa. Me sovittiin säännöistä, allekirjoitettiin vuokrasopimus ja se makso puolen vuoden vuokrat puhtaana käteen. Pitkin kesää Manninen kehuskeli, että on se mukavaa, kun Suomen saloilta löytyy vielä sellaisia ihmisiä, joilla on arvot kohdallaan. Näillä mentiin aina jouluun asti. Tapaninpäivänä tuli ekat ikävät uutiset. Kerhotiloissa oli raiskattu nuori nainen. Manninen totesi, että naisen oma vika. Uudenvuodenyönä kerhotiloissa suoritettiin törkeä pahoinpitely. Amerikkalainen koriksenpelaaja oli ostarilla isketty sähköpampulalla tainnoksiin, raahattu kerhotiloihin ja hakattu sohjoksi. Manninen huokasi, että onneksi se oli musta eikä valkoinen, mutta sitten helmikuun alussa tuli viimeinen tikki. Se oli tää mistä lehdissäkin on kirjoitettu, paloittelusurma, joka vaati kaksi uhria. Toinen niistä oli Manninen. 


\section{Outro mundo, XIII}

Rosa Liksom

Tradução do finlandês:

Pasi Loman

O nosso prédio tem um ótimo salão de festas. Antigamente, quando muitas crianças moravam no prédio, era usado o tempo todo. Agora que não há mais crianças, nós alugamos o espaço para terceiros. Primeiro, o clube de arte Picasso alugou o espaço. Funcionou bem durante a primeira semana, mas, depois que eles começaram a pintar, o cheiro de aguarrás subiu pelos encanamentos e isso causou problemas. O senhor Manninen, que mora no terceiro andar, reclamou, bem como a viúva do sexto andar. Então eu precisei dizer para o coordenador do clube que aquilo não ia funcionar. Por dois anos o salão ficou vazio, sem uso nenhum, mas quando o condomínio precisou de dinheiro, Manninen sugeriu que alugássemos o espaço novamente para um clube sem cheiro. Em um anúncio no jornal Metro, achei o clube Forma. O clube tinha o apoio da Cruz Vermelha da Finlândia, que prometeu pagar o aluguel sempre em dia. Fiz essa sugestão para Manninen e ele se animou. No começo eles não causaram problema nenhum. Todos na turma estavam na faixa dos 80 anos. Eles jogavam bingo ou conversavam sobre imagens de ressonância magnética e homeopatia. Mas depois que o outono virou inverno, as perturbações começaram. Certa vez um dos membros do clube sofreu um ataque cardíaco e tivemos de chamar uma ambulância. Logo depois, o voluntário que estava organizando o clube morreu durante uma sessão do clube de leitura. Um carro fúnebre foi chamado. Manninen ficou irritado e pediu que eu ligasse pra Cruz Vermelha para dizer que aquilo tinha acabado. Eu liguei e mais uma vez o salão de festas ficou sem uso. Porém, queríamos fazer uma reforma nos terraços, e precisaríamos de dinheiro para isso. Achei um anúncio no jornal Helsingin Sanomat em que a Irmandade estava procurando um lugar para o seu clube. Mostrei o anúncio para Manninen, e Manninen disse que parecia bom, pois de uma maneira agradável o nome do clube se referia a Karjala, o território que a Finlândia perdera na guerra contra a Rússia. Eu liguei e marcamos uma reunião com o secretário-geral do clube. Ele era um jovem patriótico, tinha até uma bandeira da Finlândia costurada na jaqueta. Combinamos as regras, assinamos o contrato e ele pagou seis meses de aluguel em dinheiro. Durante o verão, Manninen disse que era muito legal que ainda se achassem na Finlândia pessoas com os valores certos. Assim fomos até o Natal. No dia 26, recebemos as primeiras más notícias. Uma jovem fora estuprada no salão de festas. Manninen comentou que tinha sido culpa da mulher. No Ano-Novo houve uma agressão brutal 
no salão. Um jogador americano de basquete foi atacado com um bastão de choque no shopping, arrastado até o clube e espancado brutalmente. Manninen ficou aliviado, pois tinha sido um negro e não um branco, mas a última gota d'água veio em fevereiro. Foi o caso que está nos jornais também: um duplo homicídio com os corpos mutilados. Uma das duas vítimas era Manninen. 